\title{
Ameliorative Effects of Cussonia arborea Methanol Root Bark Extract on Histomorphology of Pancreas of Alloxan-Induced Diabetic Rats
}

\author{
Patrick E. ABA*, Isaac U. ASUZU \\ University of Nigeria, Department of Veterinary Physiology and Pharmacology, Nsukka, Enugu State, \\ Nigeria;patrick.aba@unn.edu.ng(*correspondingauthor);iasuzu@yahoo.ie
}

\begin{abstract}
Diabetes mellitus is an endocrine and a metabolic disease resulting from the destruction of pancreatic beta cells; thus assessment of the pancreas in diabetic rats is important in monitoring therapy. The hereby study assessed pancreatic status of diabetic rats treated with methanol root bark extract of Cussonia arborea. A total of seventy two (72) male albino wistar rats weighting between 100-105 g were assigned into six (6) groups of twelve (12) rats per group. Groups 1-5 were diabetic infected by single intraperitoneal injection with alloxan monohydrate, at the dose of $160 \mathrm{mg} / \mathrm{kg}$ and treated with $62.5,125,250 \mathrm{mg} / \mathrm{kg}$ bw of the extract, $2 \mathrm{mg} / \mathrm{kg} \mathrm{bw}$ glibenclamide and $10 \mathrm{ml} / \mathrm{kg}$ distilled water (DW) respectively, while the non diabetic rats, represented by Group 6, received $10 \mathrm{ml} / \mathrm{kg} \mathrm{DW}$ and served as normal control rats. The treatment was applied daily through the oral route for 84 days. At the end of the experiment, the pancreas organs were acquired under light ether anaesthesia for histomorphometric assessment. The results indicated that the cells of the islet of langerhans of the diabetic untreated rats (Group 5) were severely depleted when compared to that of the normal rats (Group 6). The islet cells of the diabetic rats treated with $125 \mathrm{mg} / \mathrm{kg}$ Cussonia arborea extract (Group 2) was comparable to that of the diabetic rats treated with glibenclamide (Group 4) and the normal control rats. It was concluded that the methanol extract of $C$. arborea, especially at the dose of $125 \mathrm{mg} / \mathrm{kg}$, ameliorated pancreatic lesions induced by diabetes occasioned by alloxan.
\end{abstract}

Keywords: Cussonia arborea, diabetic rat, histopathology, pancreas

\section{Introduction}

Diabetes mellitus is an endocrine and a metabolic disease consequent upon insulin lack and sequel to hyperglycemia (Celik et al., 2002). Hyperglycemia itself produces the classical signs and symptoms of polyuria, polydipsia, polyphagia and glucose urea. Prolonged hyperglycemia predisposes diabetics to oxidative stress, which precipitates complications such as nephropathy, neuropathy, angiopathy and retinopathy (Dewanjee et al., 2008). The disease is very common in humans and animals with prevalence rate varying from 1-50\% (King and Rewers, 1993).

Experimental diabetes in rodents can be induced by alloxan monohydrate which causes necrosis of the pancreatic beta cell. This will result to elevation of fasting blood glucose levels since insulin production is impaired (Etuk, 2010). Insulin is responsible for metabolizing "dragging" blood glucose to the cells. Inactivation of glucokinase, production of free radicals and changes in the normal physiology of intracellular calcium have been proposed as the possible cause of the toxic action of alloxan on pancreatic beta cells (Szukudelski, 2001). The pancreatic beta cells readily uptake the alloxan (because of its structural resemblance to glucose) and thus precipitates the toxic injury to the cells (Lenzen, 2008).

For a very long time now, plants have been used in the management of diabetes mellitus. However, these effects are usually exaggerated, unscientific or unstandardized. Cussonia arborea is a tropical plant belonging to the family of Araliaceae, with about twenty species (Tennant, 2010). Folklorically, the plant is used in the treatment of malaria, fungi diseases, chronic diarrhea and diabetes (Kinsangau et al., 2007; Amadou et al., 2008; De Villiers et al., 2010). The antioxidant potentials of the plant had earlier been reported (Aba et al., 2014).

The current study was therefore tailored to investigate the possible ameliorative effects of treating alloxan-induced diabetic rats with different graded doses of methanol root bark extract of Cussonia arborea on histomorphometry of the pancreas.

\section{Materials and Methods}

\section{Experimental animals}

Male albino rats' weighting between 100-105 g were obtained from the Department of Veterinary Physiology and Pharmacology, University of Nigeria, Nsukka laboratory animal house. The rats were randomly assigned into 6 groups of 12 rats per group. Diabetes was induced in groups 1-5, while the rats in group 6 served as normal (non infected) control rats. The rats were acclimatized for two weeks. The environmental temperature where the animals were housed varied between 28 $32^{\circ} \mathrm{C}$. The animals were kept in stainless wire mesh cages and provided with good clean water ad libitum. They were fed with standard commercial feed (Guinea ${ }^{R}$ growers). The experimental 
278

protocol used in this study was approved by the ethics committee of the University of Nigeria, Nsukka, and conforms with the guide to the care and use of animals in research and teaching of University of Nigeria, Enugu state, Nigeria (ECUN: 2015/58/702).

\section{Plant material}

The root bark of the plant material (Cussonia arborea) used in this study was collected from Orukpa Local Government Area of Benue state and identified by a plant taxonomist, at the International Centre for Ethnomedicine and Drug Development, Echara, Aku Road, Nsukka.

\section{Preparation of the plant extract}

Cold maceration method of extraction was employed. The root bark of $C$. arborea was air dried at a very low intensity of sunlight to avoid denaturation of the active ingredients. It was pulverized and stored in an air tight container pending its usage. About $1 \mathrm{~kg}$ of the powdered stem bark was soaked in 51 of $80 \%$ methanol (Sigma Aldrich, UK) with intermittent shaking every $2 \mathrm{~h}$ for $48 \mathrm{~h}$. The mixture was filtered using Whatmann No 1 filter paper. The filtrate was concentrated using rotary evaporator and the extract stored as $C$. arborea extract $(\mathrm{CAE})$ at $4^{\circ} \mathrm{C}$.

\section{Induction of experimental diabetes mellitus}

Diabetes was induced in rats using the method described by Prince and Menon (1998). The rats were injected with alloxan monohydrate (Sigma Aldrich, UK) dissolved in distilled water at the dose of $160 \mathrm{mg} / \mathrm{kg}$ body weight, intraperitoneally, after overnight fasting $(18 \mathrm{~h})$. Before the injection with alloxan monohydrate, the FBS levels of the rats were taken using AccuCheck glucometer. This was done by tail snip of the rats and allowing blood to drop on the glucometer strip. The value was read off on the screen of the glucometer. After induction, the rats were kept in clean stainless cages and fed with commercial feed and were also given clean water for about 2 days before they came down with diabetes. On the $2^{\text {nd }}$ day, diabetes was confirmed. The rats were fasted overnight before the assessment of their glucose blood status on the $2^{\text {nd }}$ day. The fasting blood glucose values above $7 \mathrm{mMol} / \mathrm{L}$ (126 mg/dl) were considered diabetic (Prince and Menon, 1998).

\section{Treatments}

The rats were treated as follows:

Group 1: Diabetic rats treated with $62.5 \mathrm{mg} / \mathrm{kg}$ C. arborea extract (CAE);

Group 2: Diabetic rats treated with $125 \mathrm{mg} / \mathrm{kgCAE}$;

Group 3: Diabetic rats treated with $250 \mathrm{mg} / \mathrm{kgCAE}$;

Group 4: Diabetic rats treated with $2 \mathrm{mg} / \mathrm{kg} g$ glibenclamide;

Group 5: Diabetic rats treated with $10 \mathrm{ml} / \mathrm{kg}$ distilled water;

Group 6: Non diabetic rats treated with $10 \mathrm{ml} / \mathrm{kg}$ distilled water.

The rats were treated orally daily for eighty four (84) days. At the end of the experiment, the pancreases were collected under light ether (Sigma Aldrich, UK) anaesthesia into a bottle containing formol saline for histopathology processing.

\section{Histopathology examination}

The histological examination of the tissues of the pancreas of male albino rats was done using the method of Drury et al. (1967).

\section{Results and Discussion}

Pancreas of normal control rats (Group 6) showed normal cells (arrow) (Fig. 1) of the islet of langerhans (H\&E X 400). The islet cells appeared fully populated (Fig. 1). The pancreas of diabetic untreated rats (Group 5) showed depopulation of the islet cells (arrow) (H\&E $\mathrm{X} 400$ ). The cells of the islet of langerhans were severely depleted (Fig. 2). Pancreas of Group 1 rats (diabetic +62.5 $\mathrm{mg} / \mathrm{kg}$ extract) showed moderate population of the islet cells of the langerhans (arrow) (H\&E X400).

The islet cells appeared moderately populated (Fig. 3). Histomorphometric assessment of pancreas of group 2 of rats (diabetic $+125 \mathrm{mg} / \mathrm{kg}$ extract) showed good population of the islet cells of the langerhans (arrow) $(\mathrm{H}$ and E X 400) comparable to the normal control rats (Fig. 4). Pancreas of Group 3 rats (diabetic $+250 \mathrm{mg} / \mathrm{kg}$ extract) showed cytoplasmic vacuolations (arrow) and moderate population of the islet cells of the langerhans (H\&E X400) (Fig. 5), while the pancreas of Group 4 rats (diabetic $+2 \mathrm{mg} / \mathrm{kg}$ glibenclamide) showed good population of the islet cells of the langerhans (arrows) (H\&E X 400) (Fig. 6).

Significant loss of the cells of the islets of langerhans of the pancreas of diabetic untreated rats (Fig. 2) was attributed to the single intraperitoneal injection of alloxan monohydrate at the dose of $160 \mathrm{mg} / \mathrm{kg}$ body weight. The formation of superoxide radicals by alloxan is responsible for destruction of pancreatic beta cell (Szukuldeski, 2001). These free radicals dismutate to hydrogen peroxide with a simultaneous flooding of cytosolic calcium ions, which cause speedy destruction of pancreatic beta cells of the islets of langerhans. This is sequel to a significant decrease in endogenous insulin secretion and the resultant increase in the blood glucose levels (Akuodor et al., 2014).

Observation of less severe degeneration and necrosis of pancreatic islet cells of the langerhans in the diabetic rats treated with $C$. arborea was attributed to the effect of the extract. These probably indicate that the extract may have prevented the free radicals generated by the alloxan

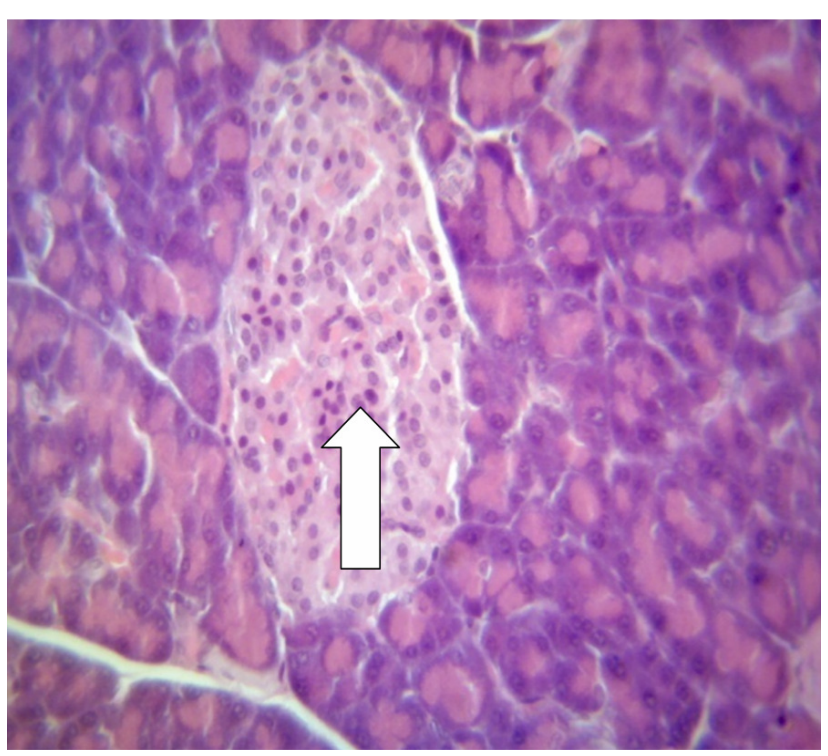

Fig. 1. Pancreas of normal control rats (Group 6) 


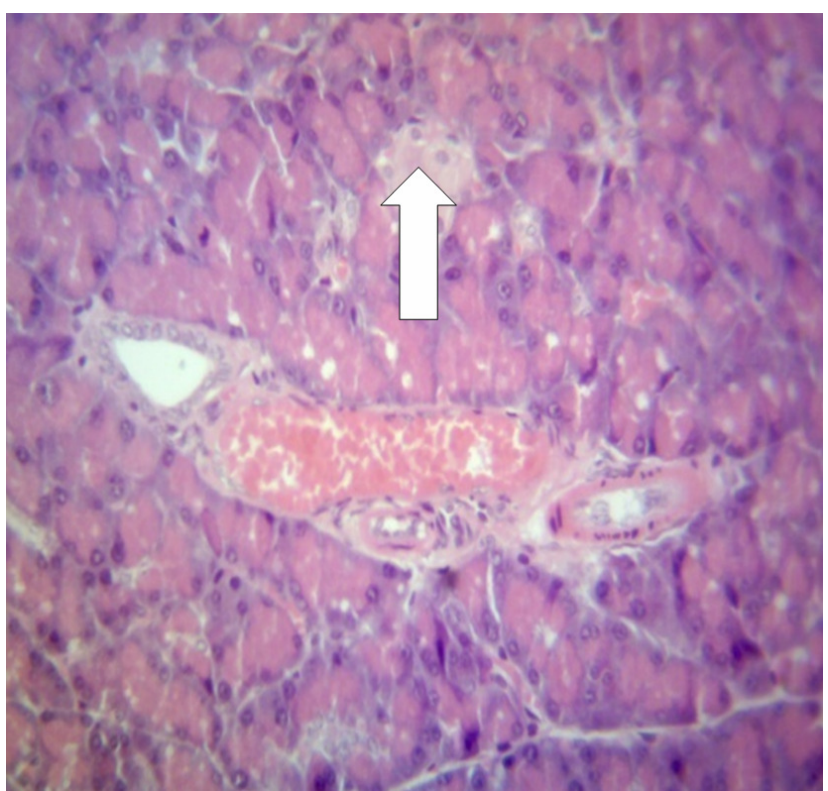

Fig. 2. Pancreas of diabetic untreated rats (Group 5)

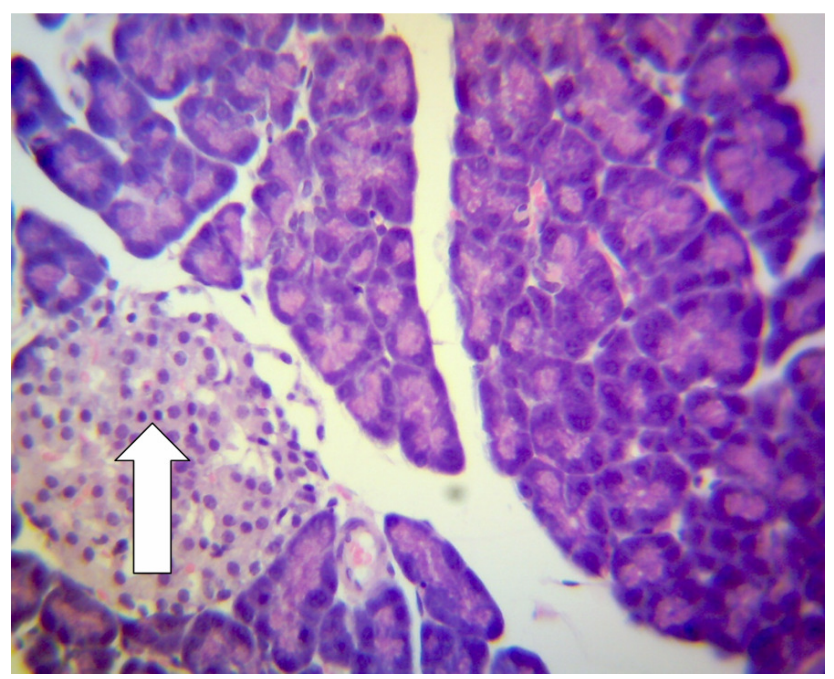

Fig. 4. Pancreas of Group 2 rats (diabetic $+125 \mathrm{mg} / \mathrm{kg}$ extract)

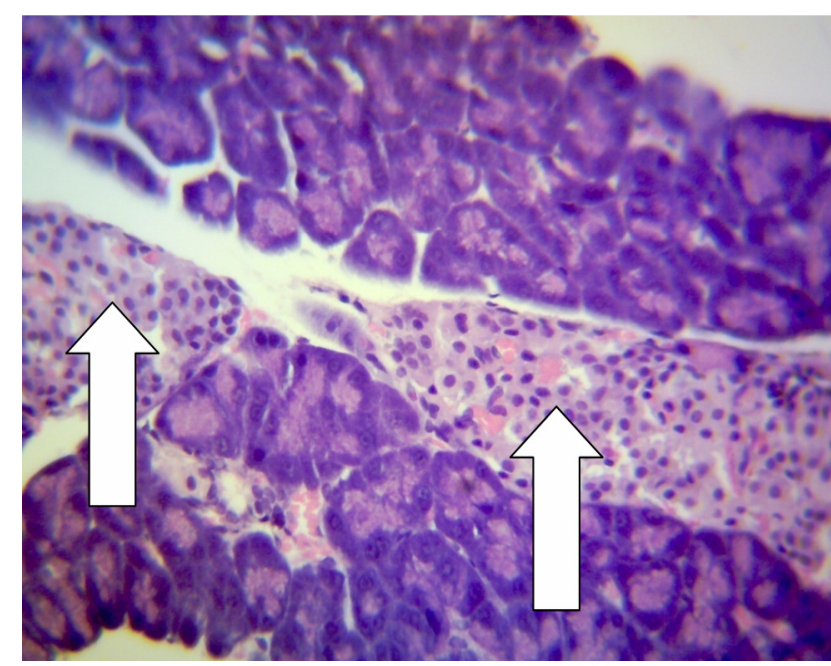

Fig. 6. Pancreas of Group 4 rats (diabetic $+2 \mathrm{mg} / \mathrm{kg}$ glibenclamide)

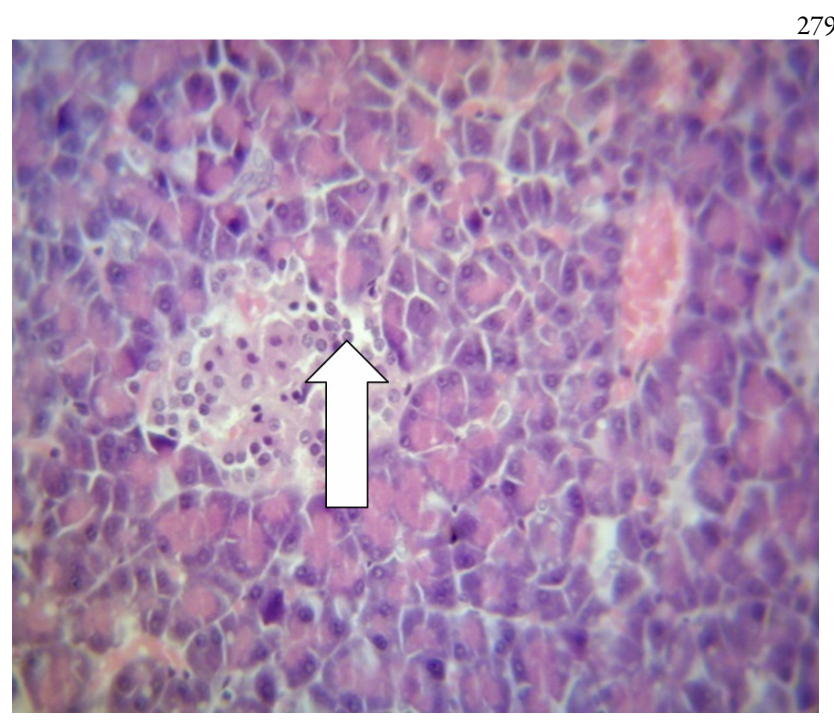

Fig. 3. Pancreas of Group 1 rats (diabetic $+62.5 \mathrm{mg} / \mathrm{kg}$ extract)

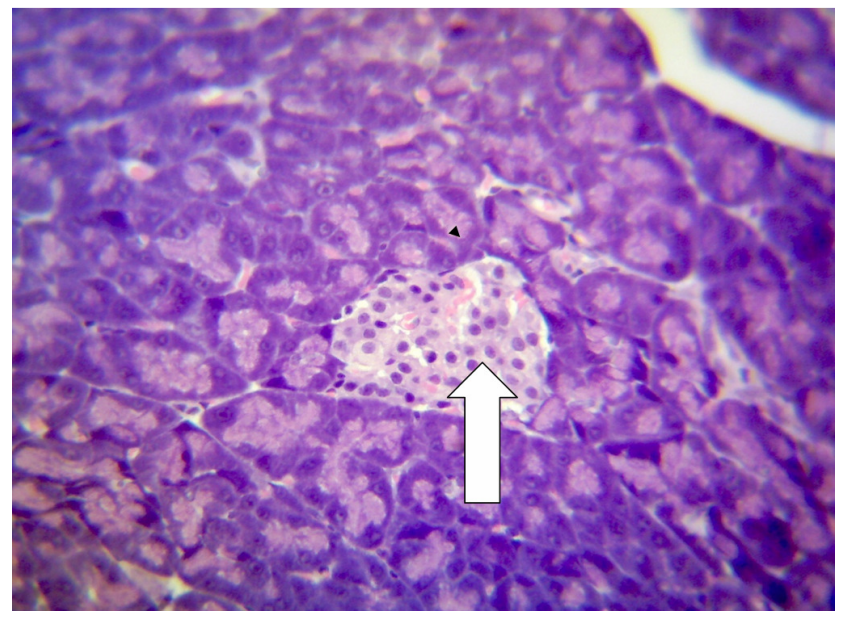

Fig. 5. Pancreas of Group 3 rats (diabetic $+250 \mathrm{mg} / \mathrm{kg}$ extract)

monohydrate in destroying the islet cells. Antioxidant potentials of $C$. arborea had earlier been reported (Aba et al., 2014).

Antioxidants are known to mop up free radicals (Aba et al., 2015). It is also possible that the extract may have stimulated the regeneration of the islet cells. FernanandezAlvarez et al. (2004) reported a regeneration of beta cell mass following treatment of streptozotocin-induced diabetic rats with tungstate for one month. The pancreatic islet cells of the diabetic rats treated with $2 \mathrm{mg} / \mathrm{kg}$ glibenclamide showed good population, indicating that the alloxan-induced lesion in this group of rats was mild. The destructive effects of alloxan on the pancreatic cells have been widely reported (Szukudelski, 2001; Lenzen, 2008; Akuodor et al., 2014) but still need to be better understood.

\section{Conclusions}

Based on the hereby results, it was concluded that treatment of diabetic rats with methanol root bark extract of C. arborea (especially at the dose of $125 \mathrm{mg} / \mathrm{kg}$ ) for 84 days mitigated injury occasioned by alloxan to the pancreas. 
280

\section{Acknowledgements}

Funding: no funding was received for this research. Conflict of interest: authors declare no conflict of interest. Ethical approval: all applicable international, national and institutional guidelines for the care and use of animals were followed.

\section{References}

Aba PE, Asuzu IU, Odo RI (2014). Antihyperglycemic and antioxidant potential of Cussonia arborea in alloxan-induced diabetic rats. Comparative Clinical Pathology 23:451-458.

Aba PE, Igwebuike DC, Onah JA (2015). Effects of various concentrations of quail egg solution on glycemia and antioxidant parameters of alloxan-induced diabetic rats. Journal of Advances in Medical and Pharmaceutical Sciences 5:1-7.

Akuodor GC, Udia PM, Bassey A, Chilaka KC, Okozie OA (2014). Antihyperglycemic and antihyperlipidemic properties of aqueous root extract of Icacina senegalensis in alloxan-induced diabetic rats. Journal of Acute Disease 3:99-103.

Amadou MD, Anna SN, DioP MN, Guata YM, Diarral HR, Gaffary AN, Babacar F (2008). Screening of plants for antidiabetic properties. Fundamental and Clinical Pharmacology 22:211-216.

Celik IE, Yegin F, Odabasoglu E (2002). Effect of experimental diabetes mellitus on plsama lactate dehdrogenase and glutamic oxaloacetic transaminase levels in rabbits. Turkish Journal of Biology 26:151-154.

De Villiers BJ, Van Vuuren SF, Van Zyl RL, Van Wyk BE (2010). Antimicrobial and antimalaria activity of Cussonia arborea (Araliaceae). Journal of Ethnopharmacology 129(2):189-196.
Dewanjee S, Bose SK, Sahu R, Mandal SC (2008). Antidiabetic effect of matured fruits of Diospyros peregrine in alloxan induced diabetic rats. International Journal of Green Pharmacy 2:95-99.

Drury RA, Wallington A, Cameroun SR (1967). Carlleton's histological techniques. Oxford University Press, New York.

Etuk EU (2010). Animal models for studying diabetes mellitus. Agriculture and Biology Journal of North America 1(2):130-134.

Fernandez-Alvarez J, Barbera A, Nadal B, Barcelo-Batkoric S, Piquer S, Claret M, Guinovart JJ, Gomis R (2004). Stable and functional regeneration of pancreatic beta-cell population in nSTZ-rats treated with tungstate beta cell neogenesis by tungstate. Diabetologia 47(3):470-477.

King H, Rewers M (1993). Global estimates from prevalence of diabetes mellitus and impaired glucose tolerance in adults. WHO ad HO diabetes reporting group. Diabetes Care 16:157-177.

Kinsangau DP, Hosea KM, Herbert VM, Cosam CJ, Zakaria HM, Pax JM, Catherine BG, Lenta NB, Krishna PD, Nobert S (2007). Plant species used in treating various HIV/AIDS-related conditions in Bukoba rural district. Journal of Ethnobiology and Ethnomedicine 3:29.

Lenzen S (2008). The mechanism of alloxan- and streptozotocininduced diabetes. Diabetologia 51:216-226.

Prince PSM, Menon VP (1998). Hypoglycemic activities of Syzygium cumini seeds effect on lipid peroxidation in alloxan diabetic rats. Journal of Clinical Biochemistry and Nutrition 25(2):81-86.

Szkudelski T (2001). The mechanism of alloxan and streptozoticin action in B cells of the rat pancreas. Physiological Research 56:537-546.

Tennant JR (2010). Cussonia arborea Hochst ex. A. Rich. Flora of Tropical East Africa 10:621. 